\title{
Valuasi Harga Saham PT Aneka Tambang Tbk sebagai Peraih IDX Best Blue 2016
}

\author{
TRIMONO, DI ASIH I MARUDDANI \\ Departemen Statistika Fakultas Sains dan Matematika Universitas Diponegoro \\ Jl. Prof. Soedarto, S.H. Tembalang, Semarang \\ e-mail: trimonopujiarto@gmail.com ; maruddani@undip.ac.id
}

\begin{abstract}
ABSTRAK
Menginvestasikan dan untuk membeli saham sebuah perusahaan merupakan salah satu bentuk investasi sektor finansial yang banyak diminati oleh para investor. Keuntungan investasi saham yang diperoleh, dapat dilihat dari nilai return saham. Harga saham adalah faktor utama yang berpengaruh terhadap nilai return saham. Namun, harga saham pada masa yang akan datang sering kali sulit untuk diprediksi. Geometric Brownian Motion (GBM) merupakan metode yang dapat digunakan untuk memprediksi harga saham jika diasumsikan return saham masa lalu berdistribusi normal. Jika dalam return saham masa lalu yang berdistribusi normal terdapat lompatan (jump), maka digunakan metode Jump Diffusion. Setelah diperoleh harga saham prediksi, dapat diukur nilai risiko investasinya. Hasil prediksi harga saham PT Aneka Tambang Tbk periode 01/12/2016 sampai dengan 31/1/2017 dengan metode GBM, diperoleh nilai MAPE sebesar 11,01\%. Berdasarkan nilai skewness dan kurtosis, dalam data return saham ANTM terdapat lompatan, sehingga harga saham ANTM lebih tepat dimodelkan dengan metode Jump Diffusion. Hasil prediksinya diperoleh nilai MAPE sebesar 1,95\%. Metode Jump diffusion lebih tepat digunakan untuk prediksi, karena menghasilkan nilai MAPE yang lebih kecil. Untuk mengukur risiko investasi harga saham prediksi yang diperoleh dari model Jump Diffusion, digunakan metode VaR simulasi Monte Carlo dengan tingkat kepercayaan 95\%. Dalam jangka waktu 1 hari setelah tanggal 25 Januari 2017 kerugian yang diterima tidak melebihi 5,617\%. Berdasarkan uji backtesting, nilai VaR harga saham prediksi dengan metode Jump Diffusion pada taraf signifikansi 5\% menghasilkan perhitungan yang akurat, karena tidak ditemukan adanya pelanggaran.
\end{abstract}

Kata Kunci: Geometric Brownian Motion, Jump Diffusion Model, Value at Risk, Backtesting

\section{PENDAHULUAN}

Sektor finansial merupakan salah satu sektor yang paling banyak diminati masyarakat untuk berinvestasi. Secara umum investasi dibagi menjadi dua kelompok yaitu investasi sektor riil (real asset investment) dan investasi sektor finansial (financial asset investment). Investasi riil merupakan investasi terhadap barang-barang yang tahan lama, seperti gedung, perumahan dan sebagainya. Sedangkan investasi finansial adalah bentuk investasi terhadap surat-surat berharga.Salah satu bentuk investasi di sektor finansial yang sekarang sedang berkembang pesat adalah investasi di pasar modal. Salah satu daya tarik terbesarnya adalah adanya potensi memperoleh keuntungan yang besar dalam waktu yang singkat. Produk investasi yang paling banyak diperdagangkan di pasar modal adalah saham.

Keuntungan yang diperoleh dari investasi saham dapat dilihat dari nilai return, dimana nilai return dipengaruhi oleh perubahan harga saham. Karena pergerakan harga saham pada dasarnya tidak dapat diprediksi secara pasti, maka diperlukan model matematis tentang pergerakan harga saham tersebut. Pada dasarnya, kegiatan investasi meskipun berpotensi memberikan keuntungan yang besar, diikuti pulang dengan risiko yang besar pula. Risiko dalam hal ini potensi kerugian yang muncul karena hasil investasi tidak sesuai dengan yang diharapkan. Salah satu metode yang dapat digunakan untuk mengukur besarnya risiko investasi adalah Value at Risk (VaR). VaR dapat membantu memperikirakan besar kerugian maksimum yang akan diterima pada suatu periode pada tingkat kepercayaan tertentu.

Salah satu metode yang digunakan untuk memprediksi harga saham di masa yang akan datang berdasarkan harga saham masa lalu adalah model Geometric Brownian Motion (GBM). Model GBM mengasumsikan bahwa return saham di masa lalu berdistribusi normal. Jika pada return saham masa lalu terdapat lompatan (jump), maka digunakan model Geometric Brownian 
Motion With Jump atau Jump Diffusion Model. Harga saham prediksi selanjutnya akan digunakan untuk memperkirakan besarnya nilai VaR. Pada penelitian ini metode penghitungan VaR yang digunakan adalah metode simulasi Monte Carlo. Selanjutnya untuk menguji akurasi nilai VaR dilakukan uji backtesting dengan menghitung nilai rasio pelanggaran.

Beberapa penelitian mengenai pemodelan harga saham telah banyak dilakukan. Abidin dan Jaffar (2014) meneliti tentang pemodelan harga saham dengan Geometric Brownian Motion pada beberapa perusahaan di Bursa Malaysia. Trimono, Maruddani, dan Ispriyanti (2017) meneliti mengenai valuasi harga saham PT Ciputra Tbk dengan Geometric Brownian Motion. Penelitian mengenai Geometric Brownian Motion dengan Jump telah dilakukan oleh Maruddani dan Trimono (2017) pada kasus data saham PT Astra Argo Lestari Tbk tahun 2017.

PT Aneka Tambang Tbk (PT Antam) merupakan perusahaan di Indonesia yang bergerak di bidang pertambangan. Pada akhir tahun 2016, Antam meraih predikat khusus "IDX Best Blue 2016" dari Bursa Efek Indonesia (BEI) setelah mencatatkan pertumbuhan kinerja terbaik dalam setahun terakhir. Prestasi ini dipengaruhi oleh besarnya jumlah investor dan pertumbuhan saham yang di anggap terbaik dari seluruh emiten yang tercatat di BEI. Predikat The IDX Best Blue 2016 diberikan untuk emiten yang pada setahun terakhir sahamnya paling diminati oleh investor, menunjukkan transaksi yang sangat aktif, memiliki pertumbuhan harga saham yang signifikan, serta berfundamental sehat.

Penelitian ini membahas valuasi saham PT Aneka Tambang Tbk, dimulai dari prediksi harga saham, perhitungan nilai VaR harga saham prediksi, dan evaluasi nilai VaR menggunakan uji backtesting.

\section{TINJAUAN PUSTAKA}

\section{Return Saham}

Return adalah tingkat pengembalian atas hasil yang diperoleh akibat melakukan investasi. Metode penghitungan return yang sering digunakan dalam analisis sekuritas adalah geometric return, dengan formulasi sebagai berikut :

$$
R\left(t_{i}\right)=\ln \left(\frac{S\left(t_{i}\right)}{S\left(t_{i-1}\right)}\right)
$$

$R\left(t_{i}\right)$ merupakan nilai return saham periode $t_{i}, S\left(t_{i}\right)$ merupakan harga saham periode $t_{i}$, dan $S\left(t_{i-1}\right)$ menyatakan harga saham periode $t_{i-1}$.

\section{Volatilitas}

Menurut Hull (2009), volatilitas harga saham dapat didefinisikan sebagai nilai standar deviasi dari return saham. Jika terdapat sejumlah $n$ return, maka nilai ekspektasi return dapat ditentukan sebagai berikut :

$$
\bar{R}=\frac{1}{n} \sum_{i=1}^{n} R\left(t_{i}\right) \quad s^{2}=\frac{1}{n-1} \sum_{t=1}^{n}\left(R\left(t_{i}\right)-\bar{R}\right)^{2}
$$

Akar dari s² (variansi) merupakan estimasi volatilitas harga saham.

\section{Skweness}

Skewness adalah derajat ketidaksimetrisan suatu distribusi. Jika kurva frekuensi suatu distribusi memiliki ekor yang lebih memanjang ke kanan (dilihat dari meannya) maka dikatakan menceng kanan (positif) dan jika sebaliknya maka menceng kiri (negatif). Secara perhitungan, skewness adalah momen ketiga terhadap mean. Distribusi simetris (distribusi normal, distribusi t, distribusi Cauchy, dan lain-lain) memiliki skewness 0 (nol).

Perhitungan skewness adalah sebagai berikut (Surya dan Situngkir, 2006):

$$
\gamma_{1}=\frac{\frac{1}{N} \sum_{i=1}^{N}\left(x_{i}-\mu\right)^{3}}{\sigma^{3}}
$$




\section{Kurtosis}

Kurtosis adalah derajat keruncingan suatu distribusi (biasanya diukur relatif terhadap distribusi normal). Kurva yang lebih lebih runcing dari distribusi normal dinamakan leptokurtik, yang lebih datar platikurtik dan distribusi normal disebut mesokurtik. Kurtosis dihitung dari momen keempat terhadap mean. Distribusi normal atau mesokurtik memiliki kurtosis $=3$, distribusi yang leptokurtik biasanya kurtosisnya $>3$, dan platikurtik $<3$.

Pengukuran kurtosis dapat diukur dengan rumus (Surya dan Situngkir, 2006):

$$
\gamma_{2}=\frac{\frac{1}{N} \sum_{i=1}^{N}\left(x_{i}-\mu\right)^{4}}{\sigma^{4}}
$$

dengan $\mu$ adalah rata-rata populasi, yang nilainya dapat digunakan dengan rata-rata sampel $\bar{x}$ (untuk sampel besar).

Distribusi yang kelebihan kurtosis (leptokurtic) ditandai dengan nilai maksimum yang sempit namun sangat besar nilainya, dan ekor distribusi yang lebih gemuk daripada ekor disribusi Normal dan kelebihan kurtosis tersebut dapat dinyatakan sebagai

$\gamma_{2}^{\prime}=\gamma_{2}-3$

\section{Peak Over Treshold (POT)}

Peak Over Threshold merupakan salah satu metode dalam Extreme Value Theory. Pada distribusi simetris, khususnya distribusi normal, akan dipunyai

Expected Loss $\int_{0}^{\mu} f(x) d x$

Unexpected Loss $\quad \int_{\mu}^{x_{\alpha}} f(x) d x$

Worse Case $\quad \int_{x_{\alpha}}^{\infty} f(x) d x$

Sehingga untuk distribusi simetris, dalam hal ini distribusi normal, jumlah data untuk kasus Worse Case adalah

$W C=100(1-\alpha) \%$

\section{Persamaan Diferensial Stokastik}

Persamaan diferensial stokastik untuk model GBM dituliskan sebagai berikut:

$d X(t)=f(X(t)) d t+g(X(t)) d W(t)$

Kemudian untuk model GBM with Jump Persamaan diferensial stokastik dituliskan sebagai berikut :

$d X(t)=f(X(t)) d t+g(X(t)) d W(t)+X(t) d J_{t}$

dengan $f(X(t)) d t$ merupakan suku drift, $g(X(t)) d t$ merupakan suku difusi, $W(t)$ merupakan gerak Brown, dan $J_{t}$ merupakan proses Jump. (Brigo et al, 2008)

\section{Model Harga Saham Geometric Brownian Motion}

Menurut Brigo et al 2008, model harga saham GBM memiliki persamaan awal : $d S(t)=\mu S(t) d t+\sigma S(t) d W(t)$

apabila terdapat fungsi $G=G(S, t)$, maka berdasarkan teorema Ito fungsi tersebut dapat dinyatakan sebagai berikut : 


$$
d G=\left(\frac{\partial G}{\partial S(t)} \mu S(t)+\frac{\partial G}{\partial t}+\frac{1}{2} \frac{\partial^{2} G}{\partial S(t)^{2}} \sigma^{2} S(t)^{2}\right) d t+\frac{\partial G}{\partial S(t)} \sigma S(t) d W(t)
$$

Misal fungsi $\mathrm{G}=\ln \mathrm{S}(\mathrm{t})$, dengan $\frac{\partial G}{\partial S(t)}=\frac{1}{S(t)}, \frac{\partial^{2} G}{\partial S(t)^{2}}=-\frac{1}{S(t)^{2}}$, dan $\frac{\partial G}{\partial t}=0$, dan perubahan harga saham periode berjalan dengan periode sebelumnya adalah satu hari, maka model akhir harga saham GBM adalah (Trimono, Maruddani, dan Ispriyanti, 2017):

$$
\hat{S}\left(t_{i}\right)=\hat{S}\left(t_{i-1}\right) \exp \left(\left(\hat{\mu}-\frac{\hat{\sigma}^{2}}{2}\right)\left(t_{i}-t_{i-1}\right)+\hat{\sigma} \sqrt{t_{i}-t_{i-1}} Z_{i-1}\right)
$$

\section{Model Harga Saham Jump Diffusion Model}

Berdasarkan Matsuda (2004), persamaan diferensial stokastik dengan jump

$$
d S(t)=\mu S(t) d t+\sigma S(t) d W(t)+S(t) d J(t)
$$

$W(t)$ merupakan gerak Brown Standard. $J(t)$ adalah proses jump standard yang didefinisikan sebagai:

$$
J(t)=\sum_{j=1}^{N_{T}}\left(Y_{j}-1\right) \text { dan } d J(t)=\left(Y_{N(t)}-1\right) d N(t)
$$

$N(t)$ adalah proses Poisson dengan intensitas $\lambda$ dengan $W(t), N(t)$, dan $Y(t)$ saling independen.

dengan $W(t)$ merupakan Gerak Brown serta nilai $\mu$ dan $\sigma$ adalah parameter dari $X$ dan $t$. Menurut Cont dan Tankov (2004) Teorema Ito untuk jump diffusion model, jika terdapat fungsi $G=G(X, t)$, maka fungsi $\mathrm{G}$ akan mengikuti persamaan berikut :

$$
d G=\left(\frac{\partial G}{\partial X(t)} \mu+\frac{\partial G}{\partial t}+\frac{1}{2} \frac{\partial^{2} G}{\partial X(t)^{2}} \sigma^{2}\right) d t+\frac{\partial G}{\partial X(t)} \sigma d W(t)+\left(G\left(X\left(t_{-}+\Delta X_{t}\right)-G\left(X\left(t_{-}\right)\right)\right)\right)
$$

Misal fungsi $\mathrm{G}=\ln \mathrm{S}(\mathrm{t})$, dengan $\frac{\partial G}{\partial S(t)}=\frac{1}{S(t)}, \frac{\partial^{2} G}{\partial S(t)^{2}}=-\frac{1}{S(t)^{2}}$, dan $\frac{\partial G}{\partial t}=0$, dan perubahan harga saham periode berjalan dengan periode sebelumnya adalah satu hari dengan $p_{0}<p_{1}<p_{2} \ldots<p_{n}$, maka model akhir harga saham dengan Jump Diffusion Model adalah (Maruddani dan Trimono, 2017):

$$
\hat{S}\left(p_{i}\right)=\hat{S}\left(p_{i-1}\right) \exp \left(\left(\hat{\mu}-\frac{\hat{\sigma}^{2}}{2}\right)\left(p_{i}-p_{i-1}\right)+\hat{\sigma} \sqrt{p_{i}-p_{i-1}} Z_{i-1}\right) \prod_{j=1}^{n_{t}} Y_{j}
$$

\section{Mean Absolute Percentage Error (MAPE)}

Menurut Shcherbakov (2013), MAPE merupakan metode yang untuk mengevaluasi nilai peramalan dengan mempertimbangkan pengaruh besarnya nilai aktual. Nilai MAPE ditentukan dengan persamaan sebagai berikut:

$M A P E=\frac{\sum_{t=1}^{n}\left|e_{t}\right|}{n} \times 100 \% \quad$ dimana $\quad\left|e_{t}\right|=\left|\frac{A_{t}-P_{t}}{A_{t}}\right|$

$A_{t}$ merupakan nilai aktual periode ke $t$. $P_{t}$ merupaka nilai peramalan pada waktu ke $t$. $n$ menyatakan banyaknya data observasi. 
Tabel 1. Skala Penilaian Akurasi MAPE

\begin{tabular}{|l|l|}
\hline \multicolumn{1}{|c|}{ Nilai MAPE } & \multicolumn{1}{c|}{ Akurasi Peramalan } \\
\hline$<10 \%$ & Akurasi peramalan sangat baik \\
\hline $11 \%-20 \%$ & Akurasi peramalan baik \\
\hline $21 \%-50 \%$ & Akurasi peramalan masih dalam batas wajar \\
\hline$>51 \%$ & Akurasi peramalan tidak akurat \\
\hline
\end{tabular}

Sumber : Shcherbakov, 2013

\section{VaR Simulasi Monte Carlo}

Danielsson (2011) mendefinisikan Value at Risk (VaR) sebagai estimasi nilai kerugian pada perdagangan portofolio, dengan peluang nilai kerugian sebenarnya lebih besar atau sama dengan VaR adalah sebesar $p$, dan peluang nilai kerugian sebenarnya lebih rendah dari nilai VaR adalah sebesar $(1-p)$.

Menurut Maruddani dan Purbowati (2009), salah satu metode perhitungan VaR adalah metode simulasi Monte Carlo. Metode Simulasi Monte carlo mengasumsikan bahwa return aset berdistribusi normal. Prosedur perhitungan VaR simulasi Monte Carlo aset tunggal adalah sebagai berikut :

1) Menentukan nilai parameter dari return, yang meliputi nilai mean () dan standar deviasi $(\sigma)$.

2) Mensimulasikan nilai return dengan membangkitkan secara random, dengan parameter yang diperoleh dari langkah (1) sebanyak $n$ buah sehingga terbentuk distribusi empiris dari return hasil simulasi.

3) Mencari estimasi kerugian maksimum pada tingkat kepercayaan (1 - a) yaitu sebagai nilai kuantil ke- $a$ dari distribusi empiris return yang diperoleh pada langkah (2), dinotasikan dengan $R^{*}$.

4) Menghitung nilai $\operatorname{VaR}$ pada tingkat kepercayaan $(1-\alpha)$ dalam periode waktu $r$ hari yaitu :

$$
\operatorname{VaR}_{(1-\alpha)}(r)=W_{0} R^{*} \sqrt{r}
$$

dengan $\mathrm{W}_{0}$ adalah dana investasi awal aset atau portofolio, $\mathrm{R}^{*}$ adalah nilai kuantil ke-a dari distribusi return, $r$ adalah periode waktu. Nilai VaR yang diperoleh merupakan kerugian maksimum yang akan diderita oleh aset tunggal.

5) Mengulangi langkah (2) sampai langkah (4) sebanyak $m$ sehingga mencerminkan berbagai kemungkinan nilai $V a R$ aset tunggal yaitu $V a R_{1}, V_{2} R_{2}, \ldots, V a R_{m}$.

6) Menghitung rata-rata hasil dari langkah (5) untuk menstabilkan nilai karena nilai VaR yang dihasilkan oleh tiap simulasi berbeda.

\section{Backtesting}

Backtesting merupakan prosedur pengujian akurasi VaR yang telah dihitung. Langkah pertama bactesting adalah membagi sampel dengan ukuran $M$ menjadi dua bagian, yaitu jendela estimasi $\left(M_{E}\right)$ dan jendela uji $\left(M_{U}\right)$. Jendela estimasi adalah kelompok observasi yang digunakan untuk perhitungan nilai $V a R$, jendela uji adalah sampel dari periode $\left(M_{E+1}\right)$ sampai dengan periode M yang digunakan untuk validasi nilai VaR (Danielsson, 2011).

\section{Rasio Pelanggaran (Violation Ratio)}

Menurut Danielsson (2011), apabila return sebenarnya pada periode tertentu lebih rendah dari nilai VaR pada periode yang sama, maka dikatakan terjadi pelanggaran. Pada periode $\left(M_{E+1}\right)$ hingga periode $M$ (panjang jendela uji), pelanggaran disimbolkan dengan $\eta_{m}$, yang bernilai 1 jika terjadi pelanggaran dan bernilai 0 jika tidak terjadi pelanggaran pada periode $m$. 
$\eta_{m}= \begin{cases}1 & \text { jika } R_{m} \leq-V_{a} R_{m} \\ 0 & \text { jika } R_{m}>-V a R_{m}\end{cases}$

$V R=\frac{v_{1}}{p_{0} \times M_{U}}$

$V R$ adalah besarnya rasio pelanggaran, $v_{1}$ adalah jumlah $\eta_{m}$ yang bernilai 1 (jumlah hari terjadi pelanggaran), $p_{0}$ merupakan probabilitas pelanggaran yang diduga.

\section{METODE PENELITIAN}

\section{Sumber Data dan Variabel Penelitian}

Data yang digunakan adalah data penutuan harga saham PT. Aneka Tambang Tbk periode 18 Agustus 2016 sampai dengan 31 Januari 2017 yang diambil dari website http://finance.yahoo.com/quote/ANTM.JK.

\section{Tahapan Analisis Data}

Tahapan analisis untuk memprediksi harga saham dan penghitungan VaR PT. Aneka Tambang Tbk adalah sebagai berikut :

1) Mengumpulkan data harga saham PT. Aneka Tambang Tbk

2) Menentukan data in sample dan dan out sample.

3) Menghitung nilai return saham dengan metode geometric return data in sample.

4) Melakukan uji normalitas data in sample return saham

5) Melakukan pemotongan data jump dari data in sample return saham dengan menggunakan metode Peak Over Treshold.

6) Melakukan estimasi parameter model harga saham GBM dan Jump Diffusion

7) Melakukan pemodelan dan prediksi harga saham.

8) Menghitung error prediksi harga saham dengan metode MAPE.

9) Melakukan uji normalitas data return saham prediksi.

10) Menghitung nilai VaR harga saham prediksi.

11) Melakukan uji backtesting nilai VaR.

\section{HASIL DAN PEMBAHASAN}

\section{Penentuan Data In Sample dan Data Out Sample}

Data penutupan harga saham yang digunakan sebagai data in sample sebanyak 74 data (periode 18/8/2016 sampai dengan 30/11/2016), untuk data out sample ditentukan sebanyak 42 data (periode $1 / 12 / 2016$ sampai dengan $31 / 1 / 2017$ ).

\section{Uji Normalitas Data In Sample Return Saham}

Uji normalitas dilakukan menggunakan uji Kolmogorv-Smirnov, diperoleh nilai D sebesar 0,159 dan nilai signfikansi sebesar 0,051. Karena nilai signifikansi lebih besar dari batas kesalahan $(0,05)$, maka data in sample return saham berdistribusi normal.

\section{Peak Over Treshold data in sample return saham}

Peak Over Treshold digunakan untuk melihat lompatan yang terjadi pada data in sample return saham ANTM. Indikasi terjadi lompatan dapat dapat dilihat dari nilai kurtosis. Apabila kurtosis bernilai lebih besar dari 3 (ekor gemuk/leptokurtosis) maka terindikasi adanya lompatan. 
Berdasarkan tabel 2, data in sample return saham ANTM memiliki nilai kurtosis lebih besar dari 3, sehingga terindikasi adanya lompatan.

Tabe1 2. Nilai Statistik Deskriptif

\begin{tabular}{|l|r|}
\hline \multicolumn{1}{|c|}{ Statistik Deskriptif } & \multicolumn{1}{c|}{ Nilai } \\
\hline Skewness & 2,48101 \\
\hline Kurtosis & 12,91703 \\
\hline
\end{tabular}

Karena data return saham ANTM terindikasi adanya lompatan, maka dilakukan perhitungan jumlah worse case data dengan extreme value menggunakan metode Peak Over Treshold. Dengan menggunakan $\alpha=10 \%$, ditentukan nilai ambang batas bawah sebesar $10 \%$, dan nilai ambang batas atas sebesar 10\% yang diberikan pada tabel 3 .

Tabel 3. Nilai Ambang Batas Data Return Menggunakan Peak Over Threshold

\begin{tabular}{|l|c|}
\hline \multicolumn{1}{|c|}{ Kuantil } & Nilai \\
\hline $\begin{array}{l}\text { Kuantil ambang batas } \\
\text { bawah }\end{array}$ & $-0,02372$ \\
\hline Kuantil ambang batas atas & 0,03195 \\
\hline
\end{tabular}

Dari tabel 3, kuantil ambang batas bawah merupakan batas bawah nilai data ekstrim atau lompatan yang ditentukan dari nilai return saham ANTM. Ambang batas bawah 10\% memiliki nilai -0,02372. Artinya nilai return yang lebih rendah dari -0,02372 merupakan lompatan yang terjadi pada data return ANTM. Sebanyak 7 data bernilai negatif merupakan lompatan. Kuantil ambang batas atas merupakan batas atas nilai data ekstrim atau lompatan yang ditentukan dari nilai return saham ANTM. Ambang batas $10 \%$ memiliki nilai 0,03195. Artinya nilai return yang lebih tinggi dari 0,03195 merupakan lompatan yang terjadi pada data return ANTM. Sebanyak 7 data bernilai positif merupakan lompatan. Sehingga dari data in sample dilakukan pemotongan 7 data terendah dan 7 data tertinggi untuk dilanjutkan ke prosedur berikutnya.

\section{Estimasi Nilai Parameter Model GBM dan Jump Diffusion}

\section{a. Estimasi Nilai Parameter Model GBM}

Model GBM memiliki 2 parameter yaitu $a$ dan $\sigma$. Return saham yang digunakan adalah return saham data in sample. Berdasarkan tabel 4, diperoleh nilai estimasi a sebesar 0,00290 dan $\sigma$ sebesar 0,03122.

Tabel 4. Estimasi nilai parameter model GBM

\begin{tabular}{|l|l|}
\hline \multicolumn{1}{|c|}{ Parameter } & Nilai \\
\hline Rata-rata return (a) & 0,00290 \\
\hline volatilitas return (o) & 0,03122 \\
\hline
\end{tabular}

b. Estimasi Nilai Parameter Model Jump Diffusion

Model Jump Diffusion memiliki 5 parameter yaitu a, $\sigma, \lambda, \mu$, $\delta$. Return saham yang digunakan yaitu return saham data in sample. Berdasarkan tabel 5, diperoleh nilai estimasi a sebesar 0,00290, $\sigma$ sebesar 0,03122, $\lambda$ sebesar 0,01376, $\mu$ sebesar 0,01477, dan $\delta$ sebesar 0,02848.

Tabel 5. Estimasi nilai parameter model Jump Diffusion

\begin{tabular}{|l|l|}
\hline \multicolumn{1}{|c|}{ Parameter } & Nilai \\
\hline rata rata return $(\alpha)$ & 0,00290 \\
\hline volatilitas return $(\sigma)$ & 0,03122 \\
\hline intensitas lompatan $(\lambda)$ & 0,01376 \\
\hline rata-rata lompatan $(\mu)$ & 0,01477 \\
\hline st.deviasi lompatan $(\delta)$ & 0,02848 \\
\hline
\end{tabular}


c. Model harga saham GBM

$\left.\hat{S}\left(t_{i+1}\right)=\hat{S}\left(t_{i}\right) \exp \left(\left(\hat{\alpha}-\frac{\hat{\sigma}^{2}}{2}\right)\left(t_{i+1}-t_{i}\right)\right)+\left(\hat{\sigma} \sqrt{t_{i+1}-t_{i}} Z_{i-1}\right)\right)$
$\left.\hat{S}\left(t_{i+1}\right)=\hat{S}\left(t_{i}\right) \exp \left(\left(0,00290-\frac{(0,03122)^{2}}{2}\right)\left(t_{i+1}-t_{i}\right)\right)+\left(0,03122 \sqrt{t_{i+1}-t_{i}} Z_{i-1}\right)\right)$

d. Model harga saham Jump Diffusion

$\hat{S}\left(t_{i+1}\right)=\hat{S}\left(t_{i}\right) \exp \left(\left(\left(\hat{\alpha}-\frac{\hat{\sigma}^{2}}{2}-\hat{\lambda}\right)\left(t_{i+1}-t_{i}\right)\right)+\left(\hat{\sigma} \sqrt{t_{i+1}-t_{i}} Z_{i-1}\right)+N_{i}\right)$

$\hat{S}\left(t_{i+1}\right)=\hat{S}\left(t_{i}\right) \exp \left(\left(\left(0,00290-\frac{(0,03122)^{2}}{2}-0,01376\right)\left(t_{i+1}-t_{i}\right)\right)+\left(0,03122 \sqrt{t_{i+1}-t_{i}} Z_{i-1}\right)+N_{i}\right)$

\section{Prediksi Harga Saham PT. Aneka Tambang Tbk}

Prediksi harga saham dilakukan untuk mengetahui perkiraan harga saham PT Aneka Tambang Tbk periode 1/12/2016 sampai dengan 31/1/2017, hasil prediksinya adalah disajikan pada tabel 6.

Tabel 6. Harga Saham Aktual dan Prediksi PT. Aneka Tambang Tbk

\begin{tabular}{|c|c|c|c|c|c|c|c|c|c|}
\hline $\mathbf{t}$ & Tanggal & Aktual & GBM & $\begin{array}{c}\text { Jump } \\
\text { Diffusion }\end{array}$ & $\mathbf{t}$ & Tanggal & Aktual & GBM & $\begin{array}{c}\text { Jump } \\
\text { Diffusion }\end{array}$ \\
\hline 1 & 01-Des-16 & 955 & 986 & 962 & 6 & 03-Jan-17 & 885 & 769 & 882 \\
\hline 2 & 02-Des-16 & 965 & 967 & 958 & 7 & 04-Jan-17 & 865 & 775 & 853 \\
\hline 3 & 05-Des-16 & 965 & 960 & 941 & 8 & 05-Jan-17 & 870 & 777 & 832 \\
\hline 4 & 06-Des-16 & 960 & 892 & 949 & 9 & 06-Jan-17 & 865 & 811 & 844 \\
\hline 5 & 07-Des-16 & 960 & 882 & 931 & 10 & 09-Jan-17 & 855 & 780 & 834 \\
\hline 6 & 08-Des-16 & 950 & 857 & 946 & 27 & 10-Jan-17 & 865 & 778 & 839 \\
\hline 7 & 09-Des-16 & 945 & 811 & 976 & 28 & 11-Jan-17 & 875 & 749 & 836 \\
\hline 8 & 13-Des-16 & 900 & 806 & 877 & 29 & 12-Jan-17 & 865 & 700 & 893 \\
\hline 9 & 14-Des-16 & 880 & 765 & 907 & 30 & 13-Jan-17 & 920 & 734 & 894 \\
\hline 10 & 15-Des-16 & 895 & 772 & 924 & 31 & 16-Jan-17 & 905 & 727 & 888 \\
\hline 11 & 16-Des-16 & 885 & 731 & 894 & 32 & 17-Jan-17 & 895 & 712 & 909 \\
\hline 12 & 19-Des-16 & 870 & 763 & 890 & 33 & 18-Jan-17 & 895 & 709 & 894 \\
\hline 13 & 20-Des-16 & 865 & 757 & 894 & 34 & 19-Jan-17 & 900 & 714 & 889 \\
\hline 14 & 21-Des-16 & 885 & 756 & 895 & 35 & 20-Jan-17 & 885 & 719 & 888 \\
\hline 15 & 22-Des-16 & 860 & 788 & 878 & 36 & 23-Jan-17 & 865 & 741 & 856 \\
\hline 16 & 23-Des-16 & 855 & 787 & 833 & 37 & 24-Jan-17 & 805 & 770 & 837 \\
\hline 17 & 27-Des-16 & 850 & 775 & 836 & 38 & 25-Jan-17 & 805 & 778 & 819 \\
\hline 18 & 28-Des-16 & 890 & 760 & 870 & 39 & 26-Jan-17 & 810 & 765 & 820 \\
\hline 19 & 29-Des-16 & 895 & 802 & 922 & 40 & 27-Jan-17 & 805 & 784 & 803 \\
\hline 20 & 30-Des-16 & 895 & 755 & 860 & 41 & 30-Jan-17 & 800 & 798 & 785 \\
\hline 21 & 02-Jan-17 & 895 & 770 & 883 & 42 & 31-Jan-17 & 800 & 793 & 806 \\
\hline
\end{tabular}




\section{Perhitungan nilai MAPE}

Melalui bantuan perangkat lunak $R$ 3.3.2, diperoleh nilai MAPE prediksi harga saham PT Aneka Tambang dengan metode GBM sebesar 11,01\% (akurasi peramalan masuk dalam kategori baik) dan nilai MAPE untuk metode Jump Diffusion sebesar 1,95\% (akurasi peramalan masuk dalam kategori sangat baik).

Berdasarkan nilai MAPE, dapat disimpulkan bahwa model terbaik untuk prediksi harga saham PT Aneka Tambang Tbk adalah model Jump Diffusion. Selanjutnya, harga saham prediksi model Jump Diffusion akan digunakan untuk menghitung perkiraan nilai VaR.

\section{Uji Normalitas Return Saham Prediksi Model Jump Diffusion}

Uji normalitas dilakukan menggunakan uji Kolmogorv-Smirnov, diperoleh nilai D sebesar 0,096 dan nilai signfikansi sebesar 0,8317. Karena nilai signifikansi lebih besar dari batas kesalahan $(0,05)$, maka data in return saham prediksi berdistribusi normal.

\section{VaR Simulasi Monte Carlo}

Sebelum melakukan perhitungan $V a R$, data return saham dibagi menjadi dua bagian yaitu jendela estimasi $\left(M_{E}\right)$ dan jendela uji $\left(M_{U}\right)$. Jendela estimasi ditentukan sebanyak 37 data dan jendela uji sebanyak 5 data. Pada penelitian ini, tingkat kepercayaan yang digunakan adalah $95 \%$.

Tabel 7. Jendela Estimasi dan Jendela Uji

\begin{tabular}{|l|c|c|}
\hline \multicolumn{2}{|c|}{ Jendela Estimasi } & \multicolumn{1}{c|}{ Jendela $\mathbf{U j i}$} \\
\hline $\boldsymbol{T}$ & $\boldsymbol{t}+\boldsymbol{M}_{\boldsymbol{E}}-\mathbf{1}$ & $\boldsymbol{V a R}\left(\boldsymbol{t}+\boldsymbol{M}_{\boldsymbol{E}}\right)$ \\
\hline $1(01 / 12 / 2016)$ & $37(24 / 12 / 2016)$ & $\operatorname{VaR}(38)(25 / 01 / 2017)$ \\
\hline $2(02 / 12 / 2016)$ & $38(25 / 01 / 2017)$ & $\operatorname{VaR}(39)(26 / 01 / 2017)$ \\
\hline $3(05 / 12 / 2016)$ & $39(26 / 01 / 2017)$ & $\operatorname{VaR}(40)(27 / 01 / 2017)$ \\
\hline $4(06 / 12 / 2016)$ & $40(27 / 01 / 2017)$ & $\operatorname{VaR}(41)(30 / 01 / 2017)$ \\
\hline $5(07 / 01 / 2017)$ & $41(30 / 01 / 2017)$ & $\operatorname{VaR}(42)(31 / 01 / 2017)$ \\
\hline
\end{tabular}

dengan bantuan software $R$ 3.3.2, Pada tingkat kepercayaan 95\% dengan 5000 kali ulangan, diperoleh nilai $V a R$ pada tabel 8.

Tabel 8. Nilai VaR Harga Saham Prediksi Jendela Uji

\begin{tabular}{|c|c|c|c|}
\hline Jendela Uji ke - & $\boldsymbol{t}$ & Tanggal & $\boldsymbol{V a R}$ \\
\hline 1 & 38 & $25 / 01 / 2017$ & $-0,05617$ \\
\hline 2 & 39 & $26 / 01 / 2017$ & $-0,05601$ \\
\hline 3 & 40 & $27 / 01 / 2017$ & $-0,05587$ \\
\hline 4 & 41 & $30 / 01 / 2017$ & $-0,05615$ \\
\hline 5 & 42 & $31 / 01 / 2017$ & $-0,05704$ \\
\hline
\end{tabular}

Berdasarkan tabel 8, jika diambil contoh untuk jendela uji ke-1 dapat disimpulkan bahwa ada keyakinan sebesar 95\% dalam jangka waktu 1 hari setelah tanggal 25 Januari 2017 kerugian yang diterima tidak melebihi 5,617\%.

\section{Backtesting}

Uji backtesting pada penelitian ini disimulasikan pada beberapa nilai dugaan probabilitas pelanggaran $\left(p_{0}\right)$, yaitu $1 \%, 2 \%, 3 \%, 4 \%$, dan $5 \%$.

1) Menghitung jumlah pelanggaran 
Tabe1 9. Penentuan nilai pelanggaran

\begin{tabular}{|c|c|c|c|c|c|}
\hline \multirow{2}{*}{ No } & \multicolumn{2}{|c|}{ Jendela Estimasi } & \multicolumn{2}{c|}{ Jendela Uji } & \multirow{2}{*}{ Pelanggaran } \\
\cline { 2 - 5 } & $\boldsymbol{t}$ (waktu) & nilai VaR & t (waktu) & Return & \\
\hline 1 & 1 s.d 37 & $-0,05617$ & 38 & -0.02355 & 0 \\
\hline 2 & 2 s.d 38 & $-0,05601$ & 39 & -0.02148 & 0 \\
\hline 3 & 3 s.d 39 & $-0,05587$ & 40 & 0.00097 & 0 \\
\hline 4 & 4 s.d 40 & $-0,05615$ & 41 & -0.02071 & 0 \\
\hline 5 & 5 s.d 41 & $-0,05704$ & 42 & -0.02280 & 0 \\
\hline
\end{tabular}

Berdasarkan tabel 9, disimpulkan bahwa pada jendela uji tidak ditemukan adanya pelanggaran, artinya semua nilai return saham memiliki nilai yang lebih kecil dibandingkan nilai VaR yang bersesuaian.

2) Rasio pelanggaran

Melalui bantuan software $R$ 3.3.2, diperoleh nilai rasio pelanggaran untuk beberapa nilai probabilitas pelanggaran disajikan pada tabel 10 .

Tabe1 10. Rasio Pelanggaran VaR Simulasi Monte Carlo

\begin{tabular}{|l|l|}
\hline \multicolumn{2}{|c|}{ Value at Risk Simulasi Monte Carlo } \\
\hline$\left(\boldsymbol{p}_{\mathbf{0}}\right)$ & Rasio Ratio \\
\hline $1 \%$ & 0 \\
\hline $2 \%$ & 0 \\
\hline $3 \%$ & 0 \\
\hline $4 \%$ & 0 \\
\hline $5 \%$ & 0 \\
\hline
\end{tabular}

Berdasarkan tabel 10, rasio pelanggaran yang bernilai 0 menunjukan bahwa perhitungan VaR dengan metode simulasi Monte Carlo dapat digunakan pada semua nilai probabilitas pelanggaran mulai dari $1 \%$ sampai dengan $5 \%$.

\section{KESIMPULAN}

Kesimpulan yang dapat diperoleh berdasarkan permasalahan yang dibahas dalam penelitian ini adalah :

1) Model harga saham PT Aneka Tambang Tbk yang terbentuk melalui Metode GBM adalah sebagai berikut :

$$
\hat{S}\left(t_{i+1}\right)=\hat{S}\left(t_{i}\right) \exp \left(\left(\left(0,00290-\frac{(0,03122)^{2}}{2}\right)\left(t_{i+1}-t_{i}\right)\right)+\left(0,03122 \sqrt{t_{i+1}-t_{i}} Z_{i-1}\right)\right)
$$

dengan nilai error prediksi sebesar $11,01 \%$.

2) Model harga saham PT Aneka Tambang Tbk yang terbentuk melalui Metode Jump Diffusion adalah sebagai berikut :

$\hat{S}\left(t_{i+1}\right)=\hat{S}\left(t_{i}\right) \exp \left(\left(\left(0,00290-\frac{(0,03122)^{2}}{2}-0,01376\right)\left(t_{i+1}-t_{i}\right)\right)+\left(0,03122 \sqrt{t_{i+1}-t_{i}} Z_{i-1}\right)+N_{i}\right)$

dengan nilai error prediksi sebesar 1,95\%.

3) Metode Jump Diffusion lebih tepat untuk memprediksi harga saham PT Aneka Tambang Tbk karena menghasilkan error pemodelan yang lebih kecil dibandingkan metode GBM. 
4) Melalui metode simulasi Monte Carlo dengan tingkat kepercayaan 95\%, diperoleh nilai VaR periode 25 Januari 2017 sebesar -0,05617, periode 26 Januari 2017 sebesar 0,05601, periode 27 Januari 2017 sebesar -0,05587, periode 30 Januari 2017 sebesar 0,05615, dan periode 31 Januari 2017 sebesar -0,05704.

5) Uji backtesting merepresentasikan bahwa pada tingkat kepercayaan 95\%, perhitungan VaR metode simulasi Monte Carlo dapat digunakan pada semua nilai probabilitas pelanggaran mulai dari $1 \%$ sampai dengan $5 \%$.

\section{DAFTAR PUSTAKA}

Abidin, S.N.Z. dan Jaffar, M.M. (2014). Forecasting Share Prices of Small Size Companies in Bursa Malaysia Using Geometric Brownian Motion. Applied Mathematics and Information Sciences. Vol 8 (1), 107-112.

Brigo et al. (2008). A Stochastic Processes Toolkit for Risk Management. Journal of Risk Management in Financial Institutions. Vol 1 (4), 5-13.

Cont, R. Dan Tankov, P. (2004). Financial Modeling with Jump Processes. Chapman \& Hall/CRC Financial Mathematics Series.

Danielsson, J. (2011). Financial Risk Forecasting. United Kingdom : John Wiley \& Sons

Hull, J.C. (2009). Options, Futures, and Other Derivative Securities. Seventh Edition. New Jersey: Prentice Hall

Maruddani, D.A.I. dan Purbowati, A. (2009). Pengukuran Value At Risk pada Aset Tunggal dan Portofolio dengan Simulasi Monte Carlo. Media Statistika. Vol 2 (2), 93-104

Rosso, G. (2015). Extreme Value Theory for Time Series using Peak-Over-Threshold Method. Working Paper.

Shcherbakov. (2013). A Survey of Forecast Error Measures. World Applied Sciences Journal. Vol 3(24), 171-176.

Surya, Y. dan Situngkir, H. (2006). Value at Risk Yang Memperhatikan Sifat Statistika Distribusi Return. Munich Personal Repech Archives, http://mpra.ub.uni-muenchen.de/895.

Trimono, Maruddani D.A.I., dan Ispriyanti, D. (2017). Pemodelan Harga Saham dengan Geometric Brownian Motion dan Value at Risk PT. Ciputra Development Tbk. Jurnal Gaussian. Vol 6 (2).

Maruddani, D.A.I. dan Trimono. (2017) Prediksi Harga Saham PT. Astra Agro Lestari Tbk dengan Jump Diffusion Model. Jurnal Riset Akuntansi Mercu Buana (submitted Mei 2017) 